\title{
Effect of Enterobacter sp. CS2 and EDTA on the Phytoremediation of Ni-contaminated Soil by Impatiens balsamina
}

\author{
Nasim Ahmad Yasin ${ }^{1}$, Waheed Ullah Khan'*, Sajid Rashid Ahmad ${ }^{2}$, Aamir Ali ${ }^{3}$, \\ Aqeel Ahmad ${ }^{1,4}$, Waheed Akram ${ }^{1,4}$ \\ ${ }^{1}$ University of the Punjab, Lahore Pakistan \\ ${ }^{2}$ College of Earth and Environmental Sciences, University of the Punjab, Lahore Pakistan \\ ${ }^{3}$ University of the Sargodha, Sargodha Pakistan \\ ${ }^{4}$ College of Plant Sciences and Technology, Huazhong Agricultural University, Wuhan China
}

Received: 18 May 2017

Accepted: 3 July 2017

\begin{abstract}
During our current study we evaluated the effect of ethylenediaminetetracetic acid (EDTA) and Enterobacter sp. CS2 on nickel stress alleviation and phytoextraction by Impatiens balsamina L in spiked soil. Nickel resistant Enterobacter sp. CS2 was isolated from soil polluted by industrial effluents. The I. balsamina seeds primed with Enterobacter sp. CS2 were raised in EDTA-supplemented soil $(10 \mathrm{mM})$ contaminated with $0,100,200$, and $300 \mathrm{mg} \mathrm{kg}^{-1} \mathrm{Ni}$ for 50 days. The effect of different treatments on plant growth attributes, nickel tolerance index, bioconcentration factor, and translocation factor were evaluated. The Ni stress reduced plant growth, carotenoids, and chlorophyll (chl) content. However, higher Ni uptake and proline contents were observed in plants growing in Ni-contaminated soils. The Enterobacter sp. CS2 inoculation further enhanced Ni uptake and proline contents in I. balsamina plants growing under Ni stress. The inoculated plants showed improved shoot length, root length, carotenoid content, chl ' $a$ ' and ' $b$ ' contents, root and shoot dry weight. The Ni tolerance index in Enterobacter sp. CS2-assisted plants was much higher compared to un-inoculated ones. The inoculated plants supplemented with EDTA enhanced 39\%, 34\%, and 30\% Ni uptake in roots respectively under 100,200 , and $300 \mathrm{mg} \mathrm{kg}^{-1}$ of $\mathrm{Ni}$ treatment as compared with un-inoculated plants. The data regarding bioconcentration factor and translocation factor showed that Ni phytoextraction capability of I. balsamina plants was significantly enhanced with the supplementation of Enterobacter sp. CS2 and EDTA.
\end{abstract}

Keywords: Enterobacter, nickel, EDTA, phytoextraction, Impatiens balsamina

*e-mail: waheedenviro@gmail.com 


\section{Introduction}

Increased industrialization, mining processes, and subsequent irrigation of heavy metal-contaminated wastewater for crop production has made heavy metal pollution a serious environmental threat throughout the world. The inorganic Ni-compounds are highly soluble in water and $\mathrm{Ni}$ is categorized as one of the most toxic metals [1]. The polluted soils may cause health issues for several living organisms [2]. Ni toxicity impedes metabolic activities and nutrient uptake in plants [3]. The plants growing in Ni-contaminated soils exhibit reduced photosynthetic and enzymatic activity, poor growth, and nutrient uptake [4]. Metals may deteriorate soil structure and fertility, which restrict successful crop cultivation and necessitates metal exclusion. The conventional remediation procedures are usually expensive and have some demerits [5]. Phytoremediation is an economical strategy that improves physicochemical characteristics of soil [6]. Various plant species have shown phytoextraction capability in metal-contaminated sites. It is an environmentally safe and economical approach for reclamation of metal-contaminated soils [7-8]. Different chelating agents may be used to improve bioavailability and translocation of contaminated metal by plants [9]. Many researchers have found that EDTA chelates heavy metals and improves phytoextraction capability of supplemented plants [10].

Some microbes are capable of reducing metal toxicity and alleviating heavy metal stress in associated plants [11]. The plant growth-promoting rhizobacteria (PGPR) improve plant growth by phosphate solubilization, auxin synthesis, and siderophores production [12-13]. PGPR may synthesize biosurfactants for the desorbtion of soil-adsorbed metal [14-15]. Moreover, the siderophores produced by PGPR enhance mobility of the metal ions toward plants and improve phytoremediation potential of the plants [16-17]. Researchers have observed that metalresistant rhizobacteria may help in stress mitigation and growth improvement in plants subjected to metal stress.

Impatiens balsamina L. is a member of the Balsaminaceae family. The core intention of current research was to assess the influence of Enterobacter sp. CS2 and EDTA on growth, biomass production, and Ni phytoextraction capability by I. balsamina plants grown under different concentrations of $\mathrm{Ni}$.

\section{Materials and Methods}

The current study was conducted in a greenhouse with mean temperatures of $23 / 15^{\circ} \mathrm{C}$ (day/night).

\section{Preparation of Soil Samples}

The soil used for the current study was obtained from the top (0-20 cm depth) of the Agricultural Farm at the University of the Punjab. The soil samples were air died, homogenized, and sieved through a plastic sieve $(5 \mathrm{~mm})$.
Soil texture, total phosphorus, and $\mathrm{pH}$ were determined [18]. Soil organic matter was analyzed following the wet digestion technique [19]. Total calcium, total magnesium, and total potassium were determined following respective protocols [20]. Total nitrogen was determined by digestion method as described by Johan Kjeldahl in 1883. The Ni present in the oven-dried soil sample was extracted by acid digestion followed by quantification with the help of an atomic absorption spectrophotometer [21].

Soil $(1.5 \mathrm{~kg})$ was transferred to sterilized plastic pots $(6 \times 5$ inch $)$ and some of the allotted pots were supplemented with 100, 200, and $300 \mathrm{mg} \mathrm{kg}^{-1} \mathrm{Ni}$ by using $\mathrm{NiSO}_{4}$. The pots containing soil without $\mathrm{Ni}$ contamination and not supplemented with Enterobacter sp. CS2 or EDTA were regarded as control. The pots were kept in the greenhouse for 30 days to maintain equilibrium of $\mathrm{Ni}$ by the daily addition of sterile distilled water.

\section{Screening and Identifying Ni-tolerant Rhizobacteria}

Soil samples (1 g) were obtained from rhizosphere of healthy I. balsamina plants cultivated in agricultural farm irrigated by water contaminated with industrial effluents. The rhizobacteria exhibiting distinctive colonies were grown in Ni-supplemented media to screen Ni-tolerant bacterial strains [22]. For evaluating Ni tolerance, $10 \mu \mathrm{l}$ bacterial inoculums were inoculated on LB agar plates supplemented with 50, 100, 200, 300, 400,

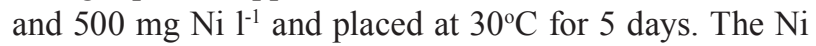
concentration over which inoculated rhizobacteria was unable to grow was considered as the threshold level for $\mathrm{Ni}$ resistance. The agar plates without Ni supplementation were deemed as control and these plates exhibited $4 \mathrm{~mm}$ diameter of bacterial colony.

The ITS region of screened Ni-tolerant rhizobacteria was amplified to identify it. For this purpose, the genomic DNA of bacteria was extracted with the help of an Enzynomics DNA extraction kit followed by performing PCR using a 2XPCR reaction mixture (Enzynomics, Daejeon, Korea) as per manufacturer instructions. The $B L A S T$ was performed to identify the amplified PCR product of screened bacteria. Moreover, the accessions number was also obtained from the National Center for Biotechnology Information (NCBI). The acquired sequences were analyzed by CLUSTAL OMEGA software to observe the similarity of screened bacterial strain with enlisted strains present in the NCBI data.

\section{Seed Inoculation}

The seeds of I. balsamina sterilized with $1 \%$ mercuric chloride were inoculated with Enterobacter sp. CS2 suspension $\left(10^{8}\right.$ cells $\left./ \mathrm{mL}\right)$ by soaking for $20 \mathrm{~min}$. The uninoculated seeds were soaked in sterile water for the same duration and taken as control. After drying seeds at room temperature for $40 \mathrm{~min}$., 5 inoculated or un-inoculated seeds were sown separately in different pots. All pots 
were irrigated on a daily basis with distilled water to sustain moisture levels up to $75 \%$ with care to avoid the leakage of heavy metal. Thinning was done after a fortnight by keeping 3 seedlings per pot. Every treatment was repeated three times to reduce experimental errors.

\section{Determining Chlorophyll, Carotenoid, and Proline Contents}

The Chl ' $a$ ', Chl 'b', and carotenoid contents were measured with the help of a spectrophotometer [23]. The proline contents were also analyzed by using a spectrophotometer at $529 \mathrm{~nm}$ [24].

\section{Determining Plant Growth and Heavy Metal Content}

The treated plants were uprooted after 50 days of sowing and washed thoroughly with de-ionized water. Roots and shoots of plants were separated and their respective length was recorded. The plant samples were dried to obtain their constant weight in an oven at $80^{\circ} \mathrm{C}$. The pre-weighted root and shoot sample were digested by using an $\mathrm{HNO}_{3} \cdot \mathrm{HClO}_{4}$ solution. The $\mathrm{Ni}$ content in digested samples was analyzed with the help of an atomic absorption spectrophotometer.

\section{Evaluation of Ni Tolerance Index}

The Ni tolerance index (TI) of $I$. balsamina was measured by the following formula:

$$
\mathrm{TI}(\%)=\frac{\text { Root or Shoot length in Ni contaminated soil }}{\text { Root or Shoot length in control conditions }}
$$

\section{Quantifying Bioconcentration Factor (BCF) and Translocation Factor (TF)}

The TF and BCF of plants/soil represent the ratio of metal concentration in shoots to roots and shoot to

Table 1. Analysis of physicochemical characteristics of soil.

\begin{tabular}{|c|c|}
\hline Characteristics & Soil \\
\hline Soil texture & Sandy loam \\
\hline Soil EC $\left(\mathrm{dS} \mathrm{m}^{-1}\right)$ & 0.35 \\
\hline Organic matter & 1.95 \\
\hline Total N $\left(\mathrm{mg} \mathrm{kg}^{-1}\right)$ & 0.82 \\
\hline Total K $\left(\mathrm{mg} \mathrm{kg}^{-1}\right)$ & 32.26 \\
\hline Total $\mathrm{Mg}\left(\mathrm{mg} \mathrm{kg}^{-1}\right)$ & 58.35 \\
\hline Total $\mathrm{Ca}\left(\mathrm{mg} \mathrm{kg}^{-1}\right)$ & 589.45 \\
\hline Total Fe $\left(\mathrm{mg} \mathrm{kg}^{-1}\right)$ & 145.74 \\
\hline Total Ni $\left(\mathrm{mg} \mathrm{kg}^{-1}\right)$ & 5.68 \\
\hline
\end{tabular}

soils, respectively. The BCF and TF of I. balsamina was analyzed accordingly [25].

\section{Data Analysis}

The experiments performed during current research were executed in a completely randomized design having 3 replicates for every treatment. Differences in data obtained were examined at $P \leq 0.05$ significance level using Microsoft Excel, DSAASTAT software. Significant differences were compared using Duncan's test.

\section{Results and Discussion}

The soil used in current research was analyzed for various physiochemical characteristics that are shown in Table 1. Soil texture was sandy and proved to be neutral as per classification system by U.S.D.A. (2005). The EC value of the soil was $0.35 \mathrm{dS} / \mathrm{m}$. It was observed that the maximum threshold levels of isolated Ni-tolerant bacteria was up to $400 \mathrm{mg} \mathrm{Ni}^{-1}$. Other studies have also demonstrated the competence of Enterobacter sp. to tolerate $\mathrm{Cu}, \mathrm{Zn}, \mathrm{Pb}$, and $\mathrm{Cd}$ toxicity [26]. The screened Ni-tolerant bacterium was identified as Enterobacter sp. CS2 and was allotted accession number Enterobacter sp. CS2: KY010200 from NCBI. The sequence analysis of this bacterium with already existing bacteria revealed that it had $100 \%, 98 \%$, and $90 \%$ alignment
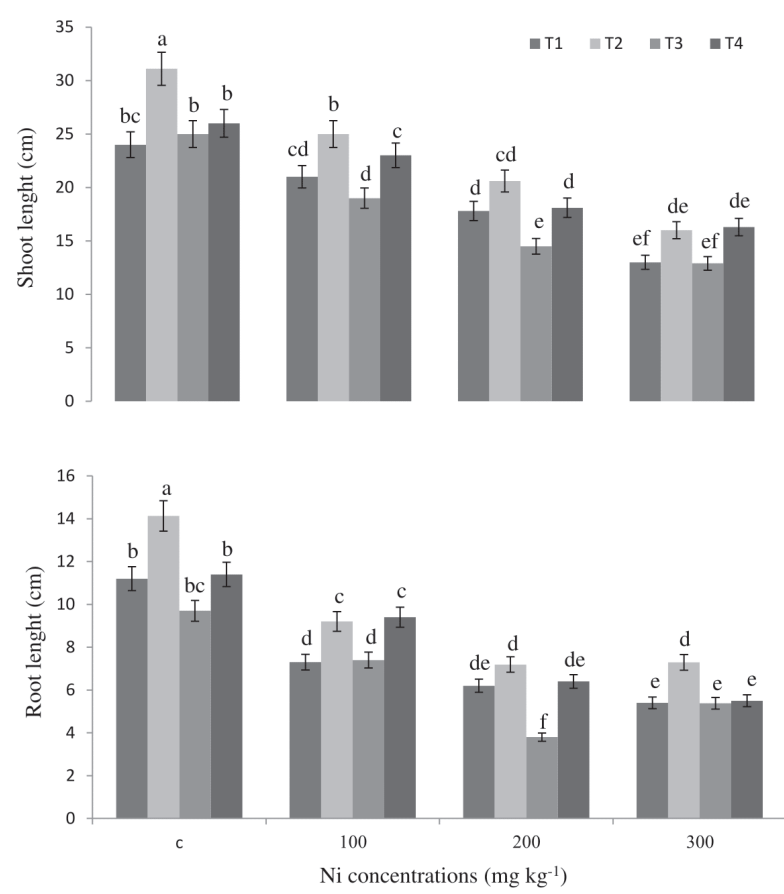

Fig. 1. Effects of Enterobacter sp. CS2 and EDTA on root and shoot length in Impatiens balsamina under Ni stress. Data shown are mean $\pm \mathrm{SD}(\mathrm{n}=3)$. Different letters show significant difference among the treatments at $P<0.05$ according to DMRT. $\mathrm{T}_{1}$ (without inoculation), $\mathrm{T}_{2}$ (bacterial inoculation), $\mathrm{T}_{3}(10 \mathrm{mM}$ EDTA) and $\mathrm{T}_{4}$ (bacterial inoculation+ $10 \mathrm{mM}$ EDTA). 

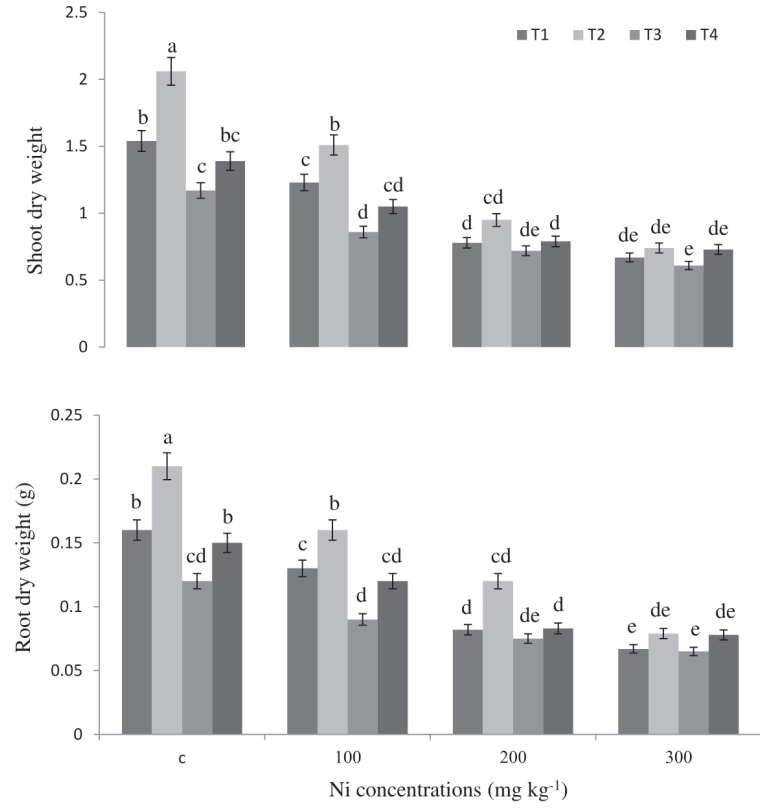

Fig. 2. Effect of Enterobacter sp. CS2 and EDTA on root and shoot dry weight in Impatiens balsamina under Ni stress. Data shown are mean $\pm \mathrm{SD}(\mathrm{n}=3)$. Different letters show significant difference among the treatments at $P<0.05$ according to DMRT. $\mathrm{T}_{1}$ (without inoculation), $\mathrm{T}_{2}$ (bacterial inoculation), $\mathrm{T}_{3}(10 \mathrm{mM}$ EDTA) and $\mathrm{T}_{4}$ (bacterial inoculation $+10 \mathrm{mM}$ EDTA).

similarity with Enterobacter sp. KX986323, Enterobacter sp. KU759034, and Enterobacter sp. KX914535, respectively.

The current study was designed to observe the effect of EDTA and Enterobacter sp. CS2 on $\mathrm{Ni}$ uptake by $I$. balsamina from Ni-contaminated soils. The un-inoculated control plants (T1) showed $11 \mathrm{~cm}$ and $24 \mathrm{~cm}$ root and shoot lengths, respectively (Fig. 1). The inoculated control (T2) plants exhibited $23 \%$ and $25 \%$ more root and shoot length, respectively, as compared to un-inoculated control (T1). Reduced root length and shoot length was observed in plants growing in Ni-contaminated soil. The un-inoculated control plants exhibited $0.17 \mathrm{~g}$ and $1.58 \mathrm{~g}$ dry weight of the roots and shoots, respectively, showing a reduction of $24 \%$ and $28 \%$ for root and shoot dry weight, respectively, as compared to inoculated control plants (Fig. 2). Although EDTA supplementation enhanced metal uptake, it reduced growth and biomass production in un-inoculated plants (Figs 1-2). EDTAsupplemented un-inoculated plants showed significantly reduced root length, shoot length, and plant biomass at $300 \mathrm{mg} \mathrm{kg}^{-1} \mathrm{Ni}$ as compared to control (Figs 1-2). It was observed that Ni contamination reduced root length, shoot length, and biomass production in un-inoculated plants. Plants subjected to Ni stress showed reduced quantities of carotenoids and chl 'a' and chl 'b' contents. These results indicate that metal toxicity impedes metabolic activities of inoculated and un-inoculated plants, resulting in decreased biomass production in plants under metal stress [27]. The increased metal uptake in contaminated soils reduces plant growth [28]. The metal contamination negatively affects physiological activities of plants [29]. Correspondingly, the enhanced lipid peroxidation and reactive oxygen species (ROs) restricts enzymatic activity in plants growing in contaminated soils. Moreover, metal toxicity can modify the structure and subsequent function of essential proteins due to which plants exhibit symptoms of chlorotic leaves, root burning, reduced growth, and poor photosynthetic activity [30-31]. The bacteria-inoculated plants exhibit higher photosynthetic activity and biomass production due to growthpromoting attributes of bacteria, including siderophore production, phosphate solubilization, synthesis of auxin, and 1-aminocyclopropane 1-carboxylate deaminase [32-33].

Higher TI values were observed in Enterobacter sp. CS2-inoculated I. balsamina plants as compared to un-inoculated and EDTA-treated plants. The TI values on shoot length basis of inoculated plants were $81 \%$, $69 \%$, and $53 \%$ under $100 \mathrm{mg} \mathrm{kg}^{-1}, 200 \mathrm{mg} \mathrm{kg}^{-1}$, and $300 \mathrm{mg} \mathrm{kg}^{-1}$, respectively, whereas TI values on root length basis in the case of inoculated plants were $61 \%$, $53 \%$, and $49 \%$ under $100 \mathrm{mg} \mathrm{kg}^{-1}, 200 \mathrm{mg} \mathrm{kg}^{-1}$, and $300 \mathrm{mg} \mathrm{kg}^{-1}$, respectively. Some other studies also reveal the augmented TI in microbe-assisted mustard plants [34].

During the present study, the plants under $\mathrm{Ni}$ stress demonstrated significantly reduced chl contents (Table 2). Reduced values of $\mathrm{Chl}$ ' $\mathrm{a}$ ' by $22 \%, 37 \%$, and $51 \%$ were recorded in un-inoculated plants under $100 \mathrm{mg} \mathrm{kg}{ }^{-1}, 200 \mathrm{mg} \mathrm{kg}^{-1}$, and $300 \mathrm{mg} \mathrm{kg} \mathrm{kg}^{-1} \mathrm{Ni}$, respectively, as compared to un-inoculated control. Inoculation of Enterobacter sp. CS2 enhanced chl 'a' by $27 \%, 24 \%, 25 \%$, and $23 \%$ under $0 \mathrm{mg} \mathrm{kg}^{-1}, 100 \mathrm{mg} \mathrm{kg}^{-1}$, $200 \mathrm{mg} \mathrm{kg}^{-1}$, and $300 \mathrm{mg} \mathrm{kg}^{-1} \mathrm{Ni}$ treatments as compared to respective un-inoculated plants. Similarly, bacterial inoculation increased the chl ' $b$ ' by $18 \%, 17 \%, 15 \%$, and $12 \%$ under $0 \mathrm{mg} \mathrm{kg}^{-1}, 100 \mathrm{mg} \mathrm{kg}^{-1}, 200 \mathrm{mg} \mathrm{kg}^{-1}$, and $300 \mathrm{mg} \mathrm{kg}^{-1} \mathrm{Ni}$ concentrations as compared to corresponding un-inoculated plants (Table 2). The carotenoid contents in plants decreased at higher concentrations of Ni. Inoculated plants (T2) showed increased carotenoid content values as compared to T1, T3, and T4 under all Ni treatments (Table 2). Enterobacter sp. CS2 inoculation enhanced carotenoid contents by $34 \%, 28 \%, 25 \%$, and $23 \%$ under $0 \mathrm{mg} \mathrm{kg}^{-1}$, $100 \mathrm{mg} \mathrm{kg}^{-1}, 200 \mathrm{mg} \mathrm{kg}{ }^{-1}$, and $300 \mathrm{mg} \mathrm{kg}^{-1} \mathrm{Ni}$ concentrations, respectively, as compared to corresponding EDTA-treated plants. Reduced quantity of carotenoids, chl 'a', and chl 'b' was also observed in plants growing in media supplemented with EDTA. The EDTA interferes with photosynthetic electron transport chain reaction, which reduces chl 'a' and chl 'b' content in EDTA-supplemented plants [35-36]. However, Enterobacter sp. CS2 inoculation improved quantity of carotenoid, chl 'a', and chl 'b' contents (Table 2). The increased biomass production in inoculated plants may be credited to increased synthesis of carotenoids along with chl ' $a$ ' and chl ' $b$ ' [37-38]. Similarly, improved chl contents, growth, and biomass production was observed 


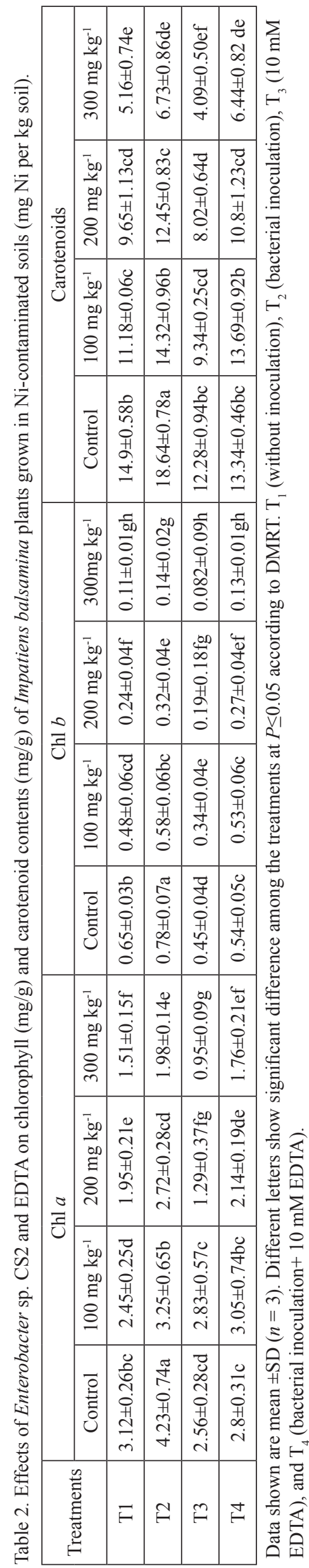

in inoculated Eruca sativa plants growing under $\mathrm{Cd}$ stress [39].

During the current study, soluble proline contents were significantly enhanced in plants grown in Ni-spiked soils as compared to the control (Fig. 3). Similarly, our results showed that enhanced values of proline contents were found with increasing concentrations of Ni stress. The inoculated plants showed higher values of proline contents under all $\mathrm{Ni}$ treatments as compared to respective un-inoculated treatments. The proline contents evaluated in all treatments were higher in roots as compared to the shoot. Moreover, higher values of proline contents were recorded in inoculated and EDTA-treated plants (T4) as compared to T1, T2, and $\mathrm{T} 3$, respectively, under $100 \mathrm{mg} \mathrm{kg}^{-1}, 200 \mathrm{mg} \mathrm{kg}^{-1}$, and $300 \mathrm{mg} \mathrm{kg}^{-1} \mathrm{Ni}$ concentrations. The maximum proline contents in root and shoot were $2.72 \mu \mathrm{g} \mathrm{g}^{-1} \mathrm{FW}$ and $1.34 \mu \mathrm{g} \mathrm{g}^{-1} \mathrm{FW}$, respectively, in T4 under $300 \mathrm{mg} \mathrm{kg}^{-1} \mathrm{Ni}$ concentrations. From these results it may be concluded that Enterobacter sp. CS2 inoculation mitigated metal stress either by restricting the entry of the metal ions in specific cells of the plants or through enhanced production of proline [40]. Moreover, PGPR improved bioavailability and uptake of essential plant nutrients [41]. Proline is involved in regulation of osmosis and $\mathrm{pH}$, scavenging of free radicals, chelation of metals, and detoxification of ROS [42]. The increased quantity of proline observed in inoculated plants during recent research verifies the role of Enterobacter sp. CS2 for stress alleviation in plants growing under Ni stress [43]. Plants growing in EDTA-

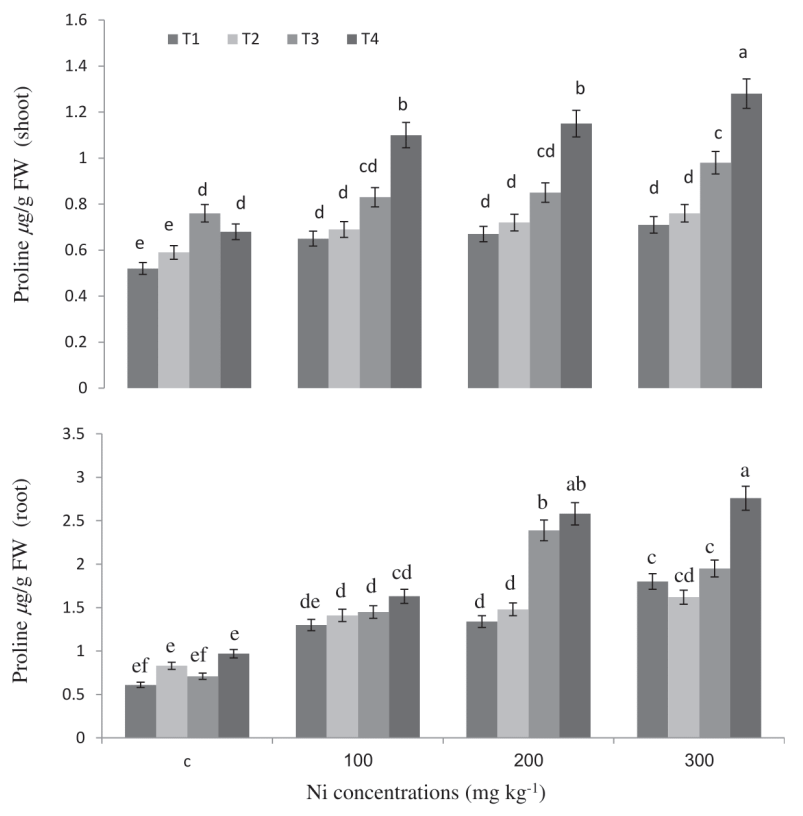

Fig. 3. Effects of Enterobacter sp. CS2 and EDTA on proline contents in root and shoot of Impatiens balsamina under $\mathrm{Ni}$ stress. Data shown are mean $+\mathrm{SD}(\mathrm{n}=3)$. Different letters show significant difference among the treatments at $P<0.05$ according to DMRT. $\mathrm{T}_{1}$ (without inoculation), $\mathrm{T}_{2}$ (bacterial inoculation), $\mathrm{T}_{2}$ (10 $\mathrm{mM}$ EDTA) and $\mathrm{T}_{4}$ (bacterial inoculation + 10 mM EDTA). 

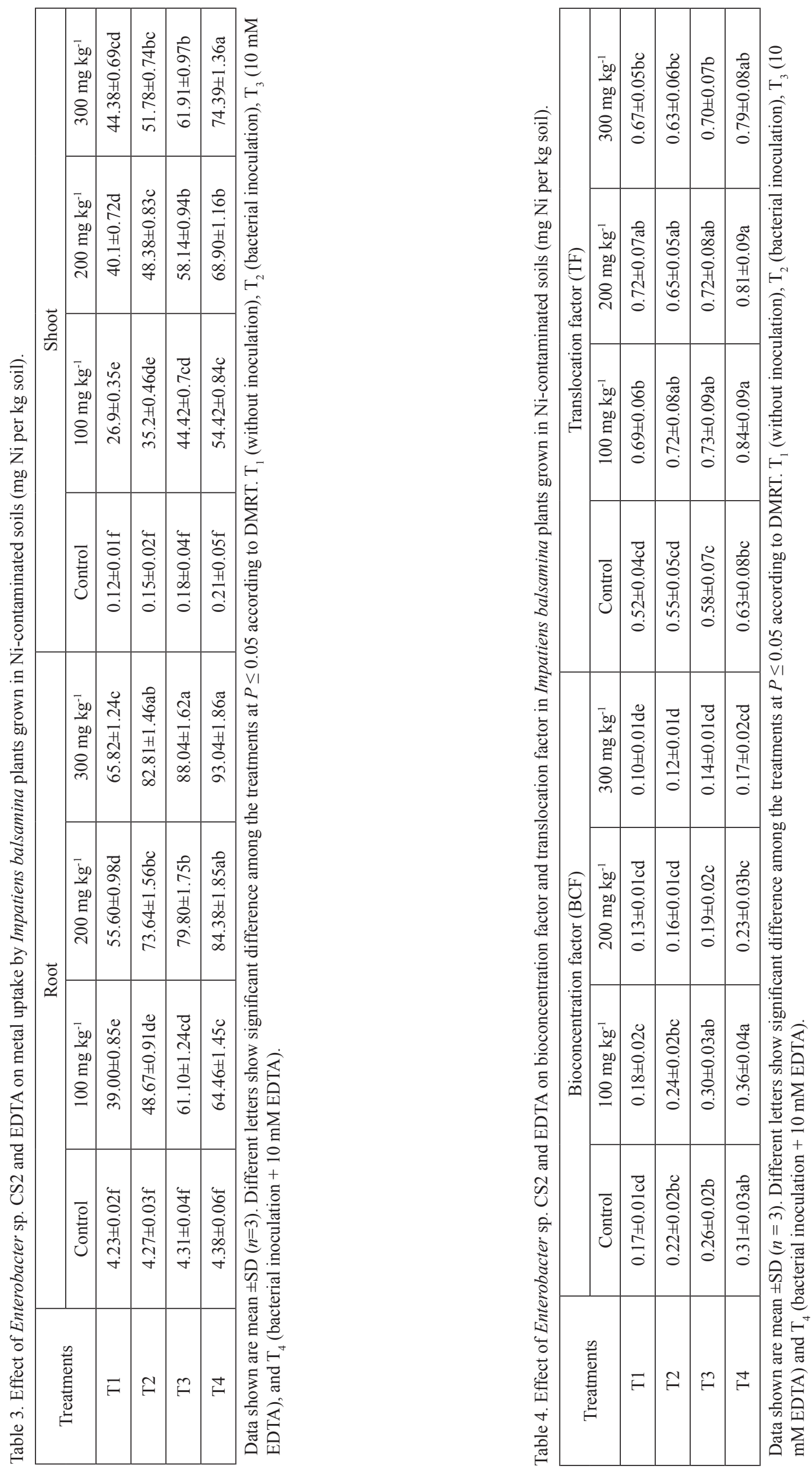
supplemented Ni-contaminated soil also exhibited a higher quantity of proline (Fig. 3). High proline contents represent $\mathrm{Ni}$ stress in plants growing in contaminated media [44]. The susceptible cultivars show less proline contents as compared to resistant ones when subjected to the same level of abiotic stress [45]. The increased proline contents improve plant resistance against heavy metal stress [46].

The current results revealed an improved trend for $\mathrm{Ni}$ uptake in plants with increasing concentrations of metal. Higher Ni accumulation was observed in roots as compared to shoots of the treated plants. The inoculated and EDTA-supplemented plants (T4) demonstrated maximum $\mathrm{Ni}$ uptake as compared to the rest of the treatments. The EDTA-supplemented inoculated plants (T4) showed $24 \%, 13 \%$, and $11 \%$ more $\mathrm{Ni}$ uptake in roots under $100 \mathrm{mg} \mathrm{kg}^{-1}, 200 \mathrm{mg} \mathrm{kg}^{-1}$, and $300 \mathrm{mg} \mathrm{kg}^{-1}$ $\mathrm{Ni}$, respectively, as compared to respective inoculated plants (T2). Similarly, Enterobacter sp. CS2-inoculated and EDTA-supplemented plants (T4) demonstrated $51 \%, 42 \%$, and $38 \%$ more $\mathrm{Ni}$ accumulation in shoots under $100 \mathrm{mg} \mathrm{kg}^{-1}, 200 \mathrm{mg} \mathrm{kg}^{-1}$, and $300 \mathrm{mg} \mathrm{kg}^{-1} \mathrm{Ni}$ treatment, respectively, as compared with corresponding un-inoculated plants (Table 3). The treated plants BCF observed at $100 \mathrm{mg} \mathrm{kg}$, $200 \mathrm{mg} \mathrm{kg}$, and $300 \mathrm{mg} \mathrm{kg}{ }^{-1} \mathrm{Ni}$ during the present study were 0.36 , 0.23 , and 0.17 , respectively. The highest values of TF at $100 \mathrm{mg} \mathrm{kg}^{-1}, 200 \mathrm{mg} \mathrm{kg}$, and $300 \mathrm{mg} \mathrm{kg}^{-1} \mathrm{Ni}$ were $0.84,0.81$, and 0.79 , respectively (Table 4). EDTA supplementation in inoculated plants enhanced $\mathrm{Ni}$ phytoextraction. The improved Ni phytoextraction may be a result of siderophore and organic acid production, enzymatic degradation, and metal chelating activity of Enterobacter sp. CS2 in inoculated plants [47]. The reduced metal phytotoxicity and increased bioavailability of $\mathrm{Ni}$ in soil enhanced $\mathrm{Ni}$ accumulation and subsequent phytoremediation potential of inoculated plants in Ni-contaminated soils [48]. The PGPRs not only improve bioavailability of metals in soil but also alter physiological activities of plants, which enhances uptake and accumulation of heavy metals in plants [49].

\section{Conclusions}

From the results of current research, it may be concluded that I. balsamina is a $\mathrm{Ni}$ accumulator and can be effectively used for phytoextraction of $\mathrm{Ni}$ contaminated soils. EDTA supplementation enhances $\mathrm{Ni}$ bioavailability from polluted soils. Moreover, seed priming with Enterobacter sp. CS2 improves Ni stress alleviation, growth, biomass production, and phytoextraction potential of Impatiens balsamina plants.

\section{Acknowledgements}

Special thanks are extended to the Department of Botany, University of Sargodha, and the academic staff of the College of Earth and Environmental Sciences for their help in executing these experiments.

\section{Conflict of Interest}

The authors declare no conflict of interest.

\section{References}

1. DIN M.I., RANI A. Recent Advances in the Synthesis and Stabilization of Nickel and Nickel Oxide Nanoparticles: A Green Adeptness. International Journal of Analytical Chemistry, 2016, 14, doi:10.1155/2016/3512145, 2016.

2. RANIERI E., BOMBARDELLI, F., GIKAS P., CHIAIA B. Soil Pollution Prevention and Remediation. Applied and Environmental Soil Science, 2016, 2, doi:10.1155/2016/9415175, 2016.

3. WILFRIED E., RAUSER. Early effects of phytotoxic burdens of cadmium, cobalt, nickel, and zinc in white beans. Canadian Journal of Botany, 56 (15), 1744, 10.1139/ b78-207, 2016.

4. KHAN M.I.R., KHAN N.A., MASOOD A., PER T.S., ASGHER M. Hydrogen Peroxide Alleviates NickelInhibited Photosynthetic Responses through Increase in Use-Efficiency of Nitrogen and Sulfur, and Glutathione Production in Mustard. Frontiers in Plant Science, 7, 44. http://doi.org/10.3389/fpls.2016.00044, 2016.

5. MOSA K.A., SAADOUN I., KUMAR K., HELMY M., DHANKHER O.P. Potential Biotechnological Strategies for the Cleanup of Heavy Metals and Metalloids. Frontiers in Plant Science, 7, 303. http://doi.org/10.3389/ fpls.2016.00303, 2016.

6. ANTONKIEWICZ J., KOŁODZIEJ B., BIELIŃSKA E. Phytoextraction of heavy metals from municipal sewage sludge by Rosa multiflora and Sida hermaphrodita. International Journal of Phytoremediation, 19 (4), 309, DOI: $\quad$ http://dx.doi.org/10.1080/15226514.2016.1225283 2017.

7. EBRAHIMIAN E., BYBORD A. Effect of organic acids on heavy-metal uptake and growth of canola grown in contaminated soil. Communications in Soil Sciences \& Plant Analysis, 45, 1715, 2014.

8. MAMDOUH A., EISSA, MOHAMED F., GHONEIM, GALAL A., EL-GHARABLY, EL-RAZEK, M.A.B.D. Phytoextraction of Nickel, Lead and Cadmium from Metals Contaminated Soils Using Different Field Crops and EDTA. World Applied Sciences Journal, 32 (6), 104, 2014.

9. ALI S.K., PAUL M., CHAUDHURY S. EDTA-enhanced phytoextraction of $\mathrm{Cd}$ and $\mathrm{Pb}$ in spiked soil with Marigold and associated potential leaching risk. International Journal of Environmental \& Agriculture Research, 2(5), 2454, 2016.

10. CAY S., UYANIK A. ENGIN M.S. EDTA Supported Phytoextraction of $\mathrm{Cd}$ from Contaminated Soil by Four Different Ornamental Plant Species. Soil and Sediment Contamination, 25 (3), 3462016.

11. KHAN W.U., AHMAD S.R., YASIN N.A., ALI A., AHMAD A., AKRAM W. Application of Bacillus megaterium MCR-8 improved phytoextraction and Stress Alleviation of nickel in Vinca rosea, International Journal 
of Phytoremediation, DOI: 10.1080/15226514.2017.1290580, 2017.

12. ANDRADES-MORENO L., DEL-CASTILLO I., PARRA R., DOUKKALI B., REDONDO-GÓMEZ S., PÉREZ-PALACIOS P., CAVIEDES M.A., PAJUELO E., RODRÍGUEZ-LLORENTE I.D. Prospecting metal resistant plant growth promoting rhizobacteria for rhizoremediation of metal contaminated estuaries using Spartina densiflora. Environmental Science \& Pollution Research, 21, 3713, 2014.

13. KHAN W.U., YASIN N.A., AHMAD S.R., ALI A., AHMED S., AHMAD A. Role of Ni-tolerant Bacillus spp. and Althea rosea L. in the phytoremediation of Ni-contaminated soils. International Journal of Phytoremediation, 19 (5), 470, DOI: 10.1080/15226514.2016.1244167, 2017.

14. JUWARKAR A.A., NAIR A., DUBEY K.V., SINGH S.K., DEVOTTA S. Biosurfactant technology for remediation of cadmium and lead contaminated soils. Chemosphere, 2, (27), 2007.

15. GADD G.M. Metals, minerals and microbes: geomicrobiology and bioremediation. Microbiology Society Journals, 156, 609, 2010.

16. BRAUD K., JÉZÉQUEL S., BAZOT T., LEBEAU. Enhanced phytoextraction of an agricultural Cr-, $\mathrm{Hg}-$ and $\mathrm{Pb}$-contaminated soil by bioaugmentation with siderophoreproducing bacteria. Chemosphere, 74, 280, 2009.

17. MESA V., NAVAZAS A., GONZÁlEZ-GIL R., GONZÁLEZ A., WEYENS N., LAUGA B., JOSE-LUIS R., SÁNCHEZ G.J., PELÁEZ A.I. Use of endophytic and rhizosphere bacteria to improve phytoremediation of arsenic-contaminated industrial soils by autochthonous Betula celtiberica. Applied \& Environmental Microbiology, 10, doi:10.1128/AEM.03411-16, 2017.

18. JACKSON M.L. Soil Chemical Analysis (II Edition). Prentice Hall of India Private Limited, New Delhi, India, 1973.

19. WALKELY A., BLACK I.A. An examination of Degtjareff methods for determining soil organic matter and a proposed modification of the chromic acid titration method. Soil Science, 37, 29, 1934.

20. RACHIDA C., LAURENT N., CHRISTELLE V., SANDRINE M., ALI K., THIERRY G. Determination of Calcium, Magnesium, Sodium, and Potassium in Foodstuffs by Using a Microsampling Flame Atomic Absorption Spectrometric Method After Closed-Vessel Microwave Digestion: Method Validation. Journal of AOAC International, 93 (6), 1888, 2010.

21. ATMA W., LAROUCI M., MEDDAH B., BENABDELI K., SONNET P. Evaluation of the phytoremediation potential of Arundo donax L. for nickel-contaminated soil. International Journal of Phytoremediation, 19 (4), 377, 2017.

22. ABOUDRAR W., SCHWARTZ C., BENIZRI E., MOREL J.L., BOULARBAH A. Soil microbial diversity as affected by the rhizosphere of the hyperaccumulator Thlaspi caerulescens under natural conditions. International Journal of Phytoremediation, 9, 41, 2007.

23. LICHTENTHALER H.K., WELLBURN A.R. Determinations of total carotenoids and chlorophylls $a$ and $b$ of leaf extracts in different solvents. Biochemical Society Transactions, 11, 591, 1983.

24. BATES L.S., WALDREN R.P., TEARE I.D. Rapid determination of free proline for water stress studies. Plant Soil, 39, 205, 1973.
25. NETTY S., WARDIYATI T., MAGHFOER M.D., HANDAYANTO E., Bioaccumulation of Nickel by Five Wild Plant Species on Nickel-Contaminated Soil. IOSR Journal of Engineering, 3, 01, 2013.

26. WANG W., DENG Z., TAN H., CAO L. Effects of Cd, Pb, $\mathrm{Zn}, \mathrm{Cu}-$ resistant endophytic Enterobacter sr CBSB1 and Rhodotorula sp. CBSB79 on the growth and phytoextraction of Brassica plants in multimetal contaminated soils. International Journal of Phytoremediation, 15 (5), 488, 2013.

27. SOBARIU D.L., FERTU D.I., DIACONU M., PAVEL L.V., HLIHOR R.M., DRĂGOI E.N., CURTEANU S., LENZ M., CORVINI P.F., GAVRILESCU M. Rhizobacteria and plant symbiosis in heavy metal uptake and its implications for soil bioremediation. N Biotechnology, 1871-6784(16), 32403. doi: 10.1016/j.nbt.2016.09.002, 2016.

28. SINGH S., PARIHAR P., SINGH R., SINGH V.P., PRASAD S.M. Heavy Metal Tolerance in Plants: Role of Transcriptomics, Proteomics, Metabolomics, and Ionomics. Frontiers in Plant Sciences, http://dx.doi.org/10.3389/ fpls.2015.01143, 2016.

29. SHEETAL K.R., SINGH S.D., ANAND A. et al. Heavy metal accumulation and effects on growth, biomass and physiological processes in mustard. Indian Journal of Plant Physiology, 21, 219. doi:10.1007/s40502-016-02218, 2016.

30. OVES M., KHAN M.S., QARI A.H., FELEMBAN M.N., ALMEELBI T. Heavy Metals: Biological Importance and Detoxification Strategies. Journal of Bioremediation \& Biodegradation, 7, 334. doi: 10.4172/2155-6199.1000334, 2016.

31. ZAHEER M.M., YASIN N.A., AHMAD S.R., KHAN W.U., AHMAD A., ALI A., REHMAN S.U. Amelioration of Cadmium Stress in Gladiolus (Gladiolus grandiflora L.) by Application of Potassium and Silicon. Journal of Plant Nutrition (Accepted), 2017.

32. VEJAN P., ABDULLAH R. KHADIRAN T., ISMAIL S., BOYCE A.N. Role of Plant Growth Promoting Rhizobacteria in Agricultural Sustainability - A Review. Molecules, 21, 573; doi:10.3390/molecules21050573 w. 2-17, 2016.

33. QIYUAN W., DODD-IAN C., BELIMOV A.A., FAN J. Rhizosphere bacteria containing 1-aminocyclopropane-1carboxylate deaminase increase growth and photosynthesis of pea plants under salt stress by limiting $\mathrm{Na}+$ accumulation. Functional Plant Biology, 43, 161, http:// dx.doi.org/10.1071/FP15200, 2016.

34. CHAUHAN J.S., RAI J.P.N. Phytoextraction of soil cadmium and zinc by microbes-inoculated Indian mustard (Brassica juncea). Journal of Plant Interactions, 4 (4), 279, DOI: 10.1080/17429140903243427, 2009.

35. OVIEDO C., RODRÍGUEZ J. EDTA: the chelating agent under environmental scrutiny. Quim. Nova, 26 (6), 901, 2003.

36. BÜCHERT A.M., CIVELLO P.M. MARTÍNEZ G.A. Characterization of Mg-dechelating substance in senescent and pre-senescent Arabidopsis thaliana leaves. Biologia Plantarum, 55, 75. doi:10.1007/s10535-011-0010-1, 2011.

37. MAHMOOD S., DAUR., AL-SOLAIMANI S.G., AHMAD S., MADKOUR M.H., YASIR M., HIRT H., ALI S., ALI Z. Plant Growth Promoting Rhizobacteria and Silicon Synergistically Enhance Salinity Tolerance of Mung Bean. Frontiers in Plant Sciences, http://dx.doi. org/10.3389/fpls.2016.00876, 2016.

38. HABIB S.H., KAUSAR H., SAUD H.M., ISMAIL M.R., OTHMAN R. Molecular characterization of stress tolerant 
plant growth promoting rhizobacteria (PGPR) for growth enhancement of rice. International Journal of Agriculture and Biology, 18, 184, 2016.

39. KAMRAN M.A., SYED J.H., EQANI S.A.M.A.S. ET AL. Effect of plant growth-promoting rhizobacteria inoculation on cadmium (Cd) uptake by Eruca sativa. Environmental Science \& Pollution Research, 22, 9275. doi:10.1007/ s11356-015-4074-x, 2015.

40. KAKAR K.U., REN X.L., NAWAZ Z., CUI Z.Q., LI B., XIE G.L., HASSAN M.A., ALI E., SUN G.C. A consortium of rhizobacterial strains and biochemical growth elicitors improve cold and drought stress tolerance in rice (Oryza sativa L.). Plant Biology Journal, 18, 471, doi:10.1111/plb.12427, 2016.

41. GOSWAMI D., JANKI N., PINAKIN T., DHANDHUKIA C., MORAL M.T. Portraying mechanics of plant growth promoting rhizobacteria (PGPR): A review. Cogent Food \& Agriculture, 2 (1), 2016.

42. KISHOR K., SREENIVASULU N. Is proline accumulation correlated with stress tolerance or is proline homeostasis a more critical issue?. Plant Cell Environ, 37, 300, doi:10.1111/pce.12157, 2014.

43. KHAN N., BANO A. Role of plant growth promoting rhizobacteria and Ag-nano particle in the bioremediation of heavy metals and maize growth under municipal wastewater irrigation. International Journal of Phytoremediation, 18 (3), 211, doi: 10.1080/15226514.2015.1064352, 2016.

44. GHARSALLAH C., FAKHFAKH H., GRUBB D., GORSANE F. Effect of salt stress on ion concentration, proline content, antioxidant enzyme activities and gene expression in Tomato cultivars. AoB PLANTS (2016): plw055doi: 10.1093/aobpla/plw055, 2016.
45. KUMAR V., KHARE T. Differential growth and yield responses of salt-tolerant and susceptible rice cultivars to individual $\left(\mathrm{Na}^{+}\right.$and $\left.\mathrm{Cl}^{-}\right)$and additive stress effects of $\mathrm{NaCl}$. Acta Physiol Plant, 38, 170. doi:10.1007/s11738-0162191-x, 2016.

46. ZOUARI M., BEN-AHMED C.H., ZORRIG W., ELLOUMI N., RABHI M., DELMAIL D., BENROUINA B., LABROUSSE P., BEN-ABDALLAH F. Exogenous proline mediates alleviation of cadmium stress by promoting photosynthetic activity, water status and antioxidative enzymes activities of young date palm (Phoenix dactylifera L.). Ecotoxicology \& Environmental Safety, 128, 100. doi: 10.1016/j.ecoenv.2016.02.015. Epub 2016 Feb 20, 2016.

47. ANTONKIEWICZ J., KOŁODZIEJ B., BIELIŃSKA E. Phytoextraction of heavy metals from municipal sewage sludge by Rosa multiflora and Sida hermaphrodita. International Journal of Phytoremediation, 19 (4), 309, DOI:http://dx.doi.org/10.1080/15226514.2016.1225283, 2017.

48. DURAND A., PIUTTI S., RUE M., ET AL. Improving nickel phytoextraction by co-cropping hyperaccumulator plants inoculated by plant growth promoting rhizobacteria. Plant and Soil February, 399 (1), 179, doi:10.1007/s11104015-2691-2, 2016.

49. FANG Q., FAN Z., XIE Y., WANG X., LI K., LIU Y. Screening and Evaluation of the Bioremediation Potential of Cu/Zn-Resistant, Autochthonous Acinetobacter sp. FQ44 from Sonchus oleraceus L. Frontiers in Plant Sciences, 7, 1487. doi: 10.3389/fpls.2016.01487, 2016. 
